\title{
Cross-bridged cyclam with phosphonate and phosphinate pendant arms: chelators for copper radioisotopes with fast complexation kinetics
}

Lucia Pazderová, ${ }^{a}$ Tomáš David, ${ }^{a, \&}$ Veronika Hlinová, ${ }^{a}$ Jan Plutnar, ${ }^{a, \#}$ Jan Kotek, ${ }^{a}$ Přemysl Lubal, ${ }^{b}$ Vojtěch Kubíček $*^{a}$ and Petr Hermann ${ }^{a}$

${ }^{a}$ Department of Inorganic Chemistry, Faculty of Science, Charles University, Hlavova 8, 12840 Prague 2, Czech Republic. Tel.: +420221951436; fax: +420221951253; e-mail: kubicek@ @atur.cuni.cz

${ }^{b}$ Department of Chemistry, Masaryk University, Kotlářská 2, 611 37, Brno, Czech Republic.

${ }^{\&}$ current address: Institute of Organic Chemistry and Biochemistry of the Czech Academy of Sciences, Flemingovo nám. 2, 16610, Prague 6, Czech Republic.

\# current address: Center for Advanced Functional Nanorobots, Department of Inorganic Chemistry, Faculty of Chemical Technology, University of Chemistry and Technology, Technická 5, Prague 6, 16000, Czech Republic.

\section{$\underline{\text { Table of content }}$}

Figure S1. Details about the synthesis of $\mathrm{H}_{4} \mathbf{L}^{1}$

Figure S2. Characterization NMR spectra of $\mathrm{H}_{4} \mathbf{L}^{1}$

Figure S3. Characterization NMR spectra of $\mathrm{H}_{4} \mathbf{L}^{2}$

Figure S4. Characterization NMR spectra of $\mathrm{H}_{2} \mathbf{L}^{3}$ S5

Table S1. Distances and angles in the system of intramolecular hydrogen bonds of $\mathrm{H}_{2} \mathbf{L}^{3} \cdot 5 \mathrm{H}_{2} \mathrm{O}$. S6

Table S2. Structural parameters of the phosphonate moieties of the $\left[\mathrm{Cu}\left(\mathrm{H}_{2} \mathbf{L}^{\mathbf{1}}\right)\right] \cdot 2 \mathrm{H}_{2} \mathrm{O}$ complex S6

Table S3. Selected bond distances and angles of the $\left[\mathrm{Cu}\left(\mathrm{H}_{2} \mathbf{L}^{1}\right)\right] \cdot 2 \mathrm{H}_{2} \mathrm{O}$ complex S7

Table S4. Hydrogen bonds lengths in the crystal structure of the $\left[\mathrm{Cu}\left(\mathrm{H}_{2} \mathbf{L}^{1}\right)\right] \cdot 2 \mathrm{H}_{2} \mathrm{O}$

Table S5. Overall protonation constants and overall stability constants of $\mathrm{Cu}(\mathrm{II})$ complexes S8

Figure S5. ${ }^{31} \mathrm{P}$ NMR shifts of ligands in the alkaline region S9

Figure S6. Formation of $\mathrm{Cu}(\mathrm{II})$ complexes as function of copper(II) concentration and $\mathrm{pH} \quad \ldots . . \quad \mathrm{S} 10$

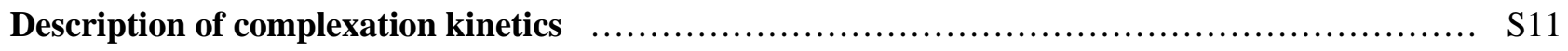

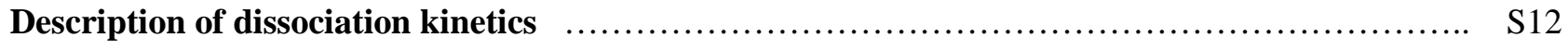

Scheme S1. Formal reaction scheme of the formation of the in-cage $\mathrm{Cu}(\mathrm{II})-\mathrm{H}_{3}$ nota complex $\quad \ldots \ldots \ldots . . . \mathrm{S} 13$

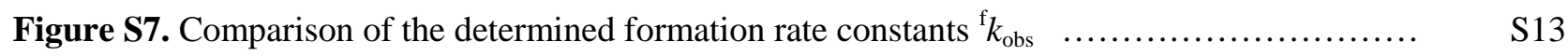

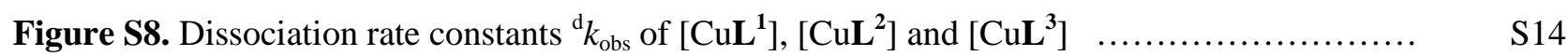

Figure S9. Comparison of dissociation rate constants ${ }^{\mathrm{d}} k_{\mathrm{obs}}$ of $\left[\mathrm{CuL}^{2}\right]$ in $\mathrm{HClO}_{4}$ and in $\mathrm{HCl} \quad$.. $\quad \mathrm{S} 15$

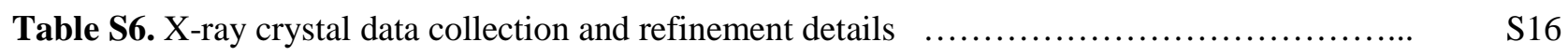

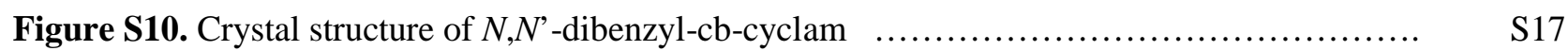


Figure S1. Typical ${ }^{31} \mathrm{P}$ NMR spectrum of the reaction mixture obtained after heating cb-cyclam, $\mathrm{H}_{3} \mathrm{PO}_{3}$ (a) and paraformaldehyde at $60-80{ }^{\circ} \mathrm{C}$. In addition to the product $\mathrm{H}_{4} \mathbf{L}^{1}$ (light blue circle) and to the expected side products - i.e., phosphoric acid $(b)$ and hydroxymethylphosphonic acid $(c)$ - undesired monomethylphosphonate cb-cyclam (red circle) and other species (\#) also formed during the reaction (A). However, at a lower temperature $\left(35^{\circ} \mathrm{C}\right)$ and with a large excess of both $\mathrm{H}_{3} \mathrm{PO}_{3}(a)$ and paraformaldehyde (15 eq. each), a prolonged reaction time (7 days) quantitatively afforded $\mathrm{H}_{4} \mathbf{L}^{\mathbf{1}}$ (B). When such a mixture was purified on a strong cation exchange resin $\left(\mathrm{H}^{+}\right.$-form), compounds $a-c$ were quantitatively removed by washing with distilled $\mathrm{H}_{2} \mathrm{O}$. Subsequent washing with $10 \%$ aqueous pyridine led (after removing pyridine through repeated evaporation with $\mathrm{H}_{2} \mathrm{O}$ ) to pure $\mathrm{H}_{4} \mathbf{L}^{\mathbf{1}}$ in zwitterionic form (C).
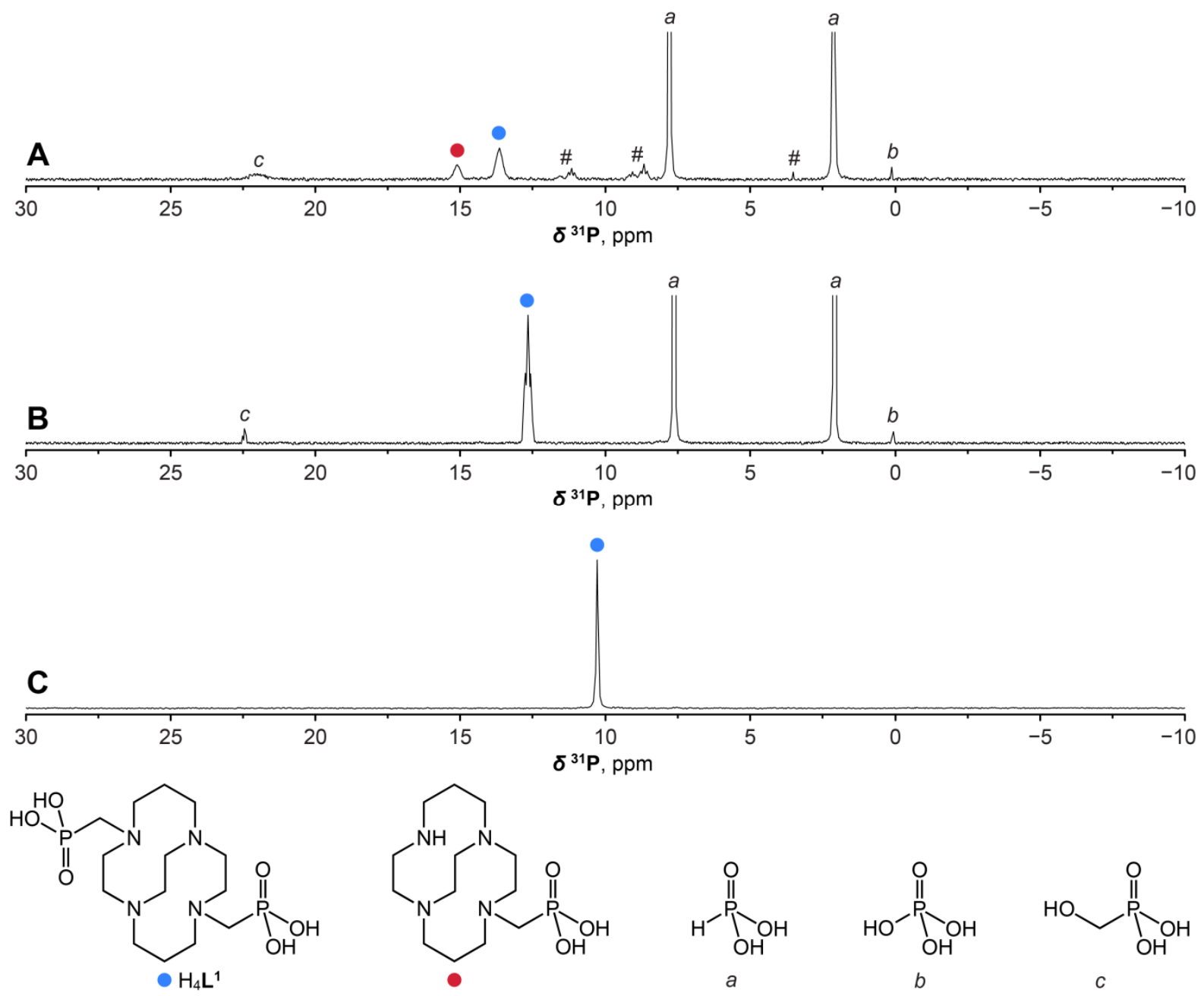
Figure S2. Characterization ${ }^{31} \mathrm{P}\left\{{ }^{1} \mathrm{H}\right\}(\mathbf{A}),{ }^{1} \mathrm{H}(\mathbf{B})$ and ${ }^{13} \mathrm{C}\left\{{ }^{1} \mathrm{H}\right\}$ (C) NMR spectra of $\mathrm{H}_{4} \mathbf{L}^{\mathbf{1}}$ in $\mathrm{D}_{2} \mathrm{O}+\mathrm{CsOD}$ $(\mathrm{pD} \sim 5)$

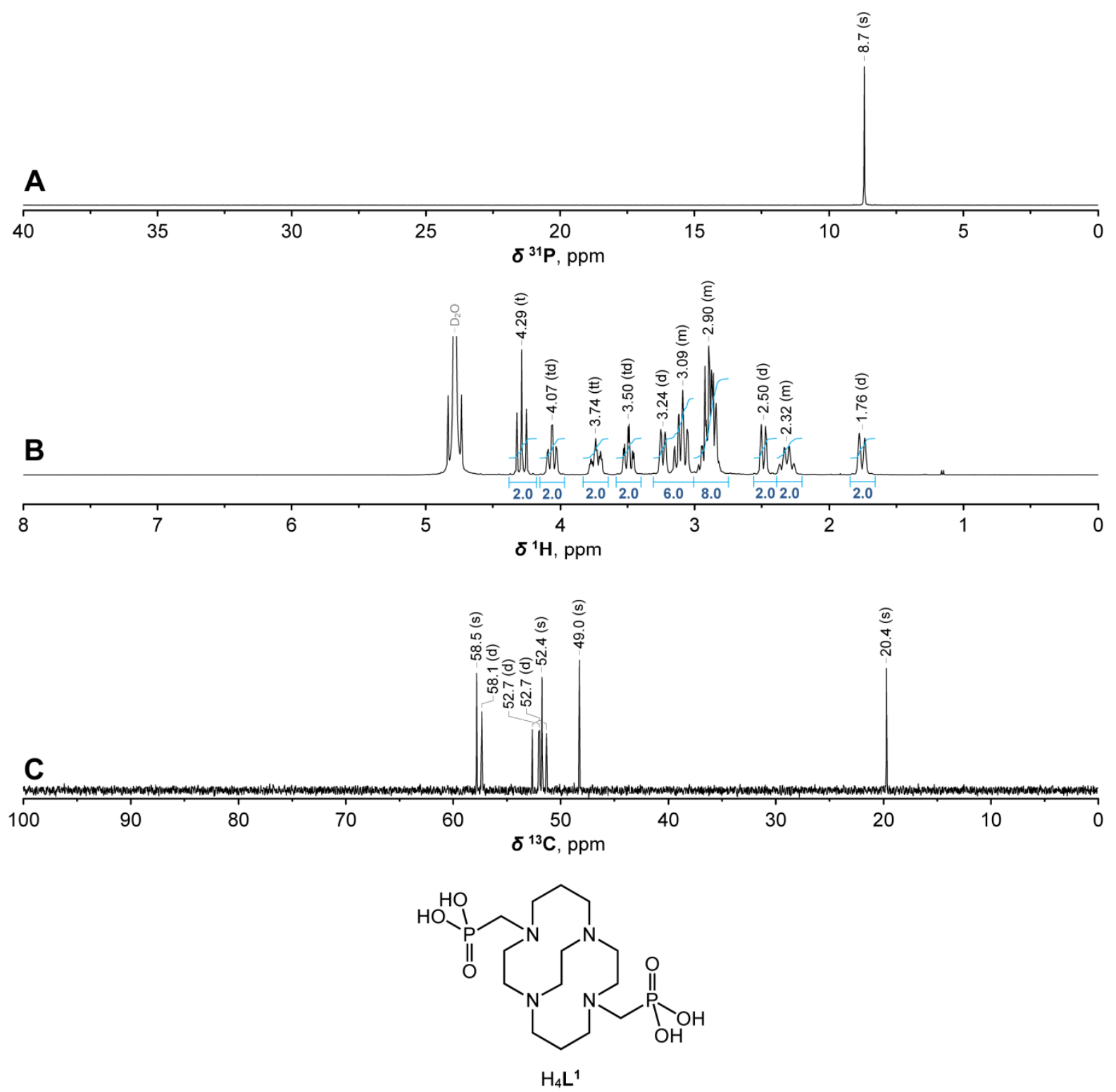


Figure S3. Characterization ${ }^{31} \mathrm{P}(\mathbf{A}),{ }^{1} \mathrm{H}(\mathbf{B})$ and ${ }^{13} \mathrm{C}\left\{{ }^{1} \mathrm{H}\right\}$ (C) NMR spectra of $\mathrm{H}_{4} \mathbf{L}^{2}$ in $\mathrm{D}_{2} \mathrm{O}+\mathrm{CsOD}(\mathrm{pD}$ $\geq 12$ ). Partial deuteration of $\mathrm{P}-\mathrm{H}$ bond is denoted by a grey double arrow (A)
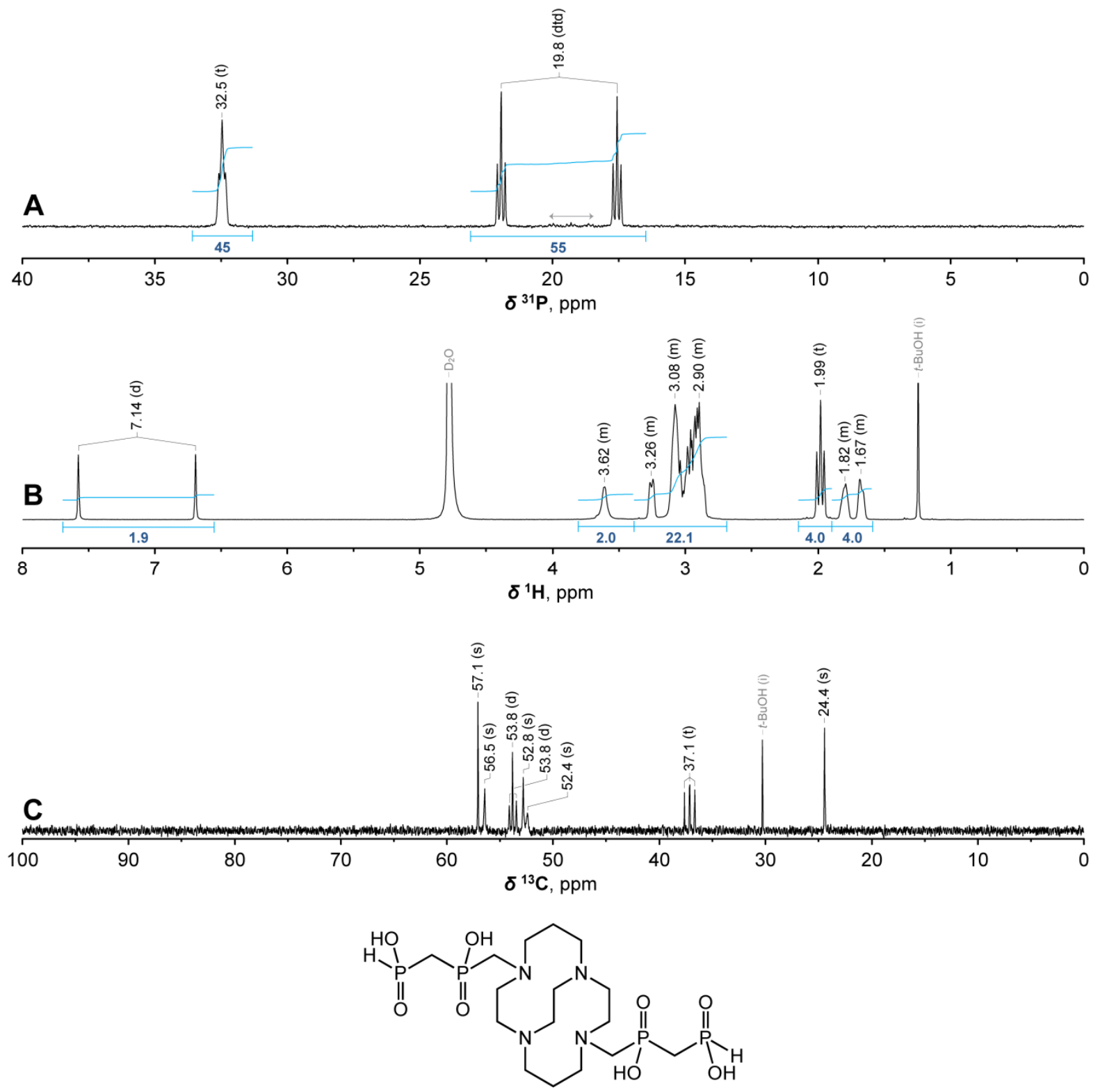

$\mathrm{H}_{4} \mathrm{~L}^{2}$ 
Figure S4. Characterization ${ }^{31} \mathrm{P}(\mathbf{A}),{ }^{1} \mathrm{H}(\mathbf{B})$ and ${ }^{13} \mathrm{C}\left\{{ }^{1} \mathrm{H}\right\}$ (C) NMR spectra of $\mathrm{H}_{2} \mathbf{L}^{\mathbf{3}}$ in $\mathrm{D}_{2} \mathrm{O}+\mathrm{CsOD}(\mathrm{pD}$ $\geq 12$ )
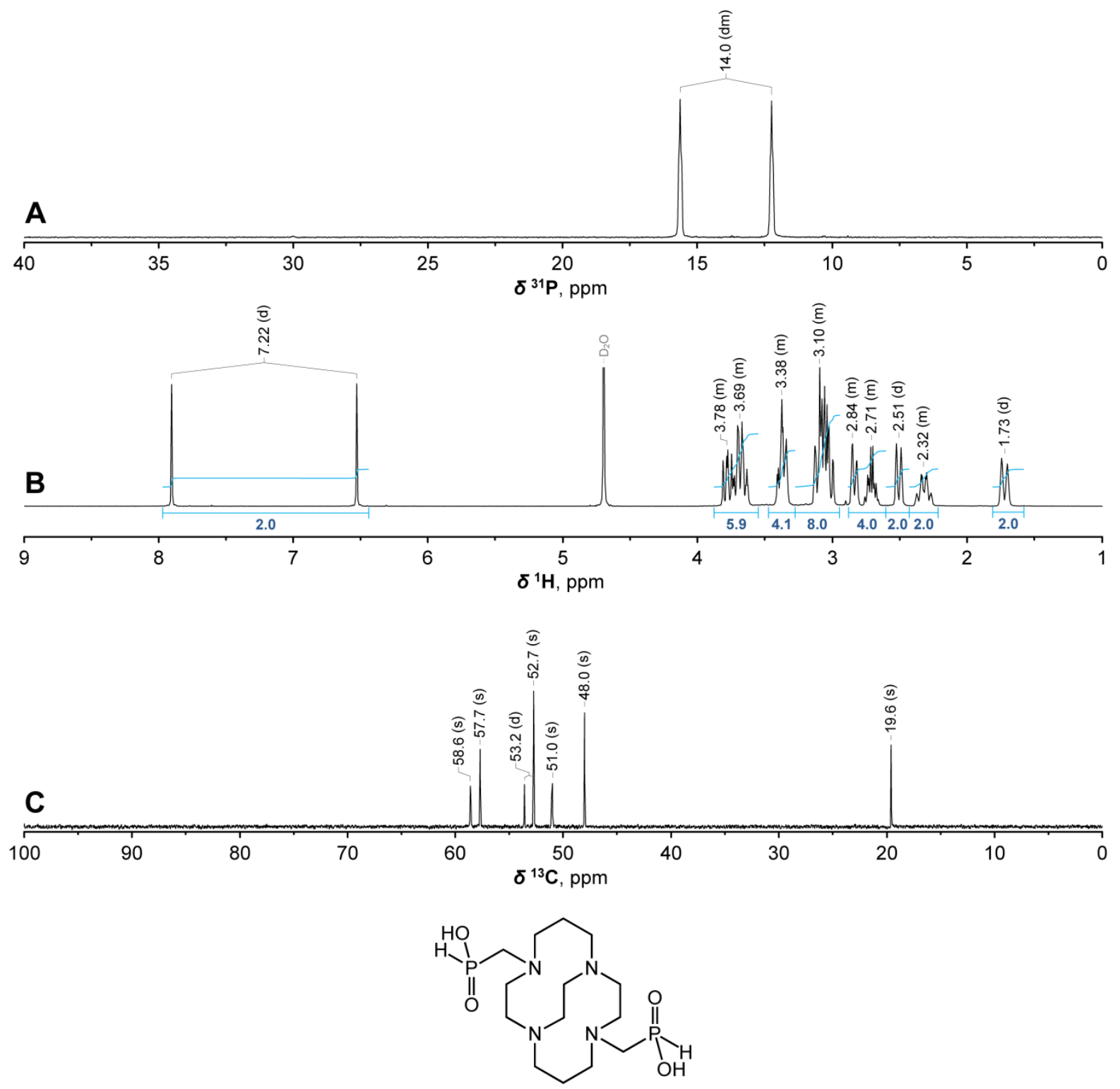

$\mathrm{H}_{2} \mathrm{~L}^{3}$ 
Table S1: Parameters of intramolecular hydrogen bonds found in the crystal structure of $\mathrm{H}_{2} \mathbf{L}^{3} \cdot 5 \mathrm{H}_{2} \mathrm{O}$

\begin{tabular}{cccccc}
\hline $\mathrm{D}-\mathrm{H}$ & $d(\mathrm{D}-\mathrm{H})(\AA)$ & $d(\mathrm{H} \cdots \mathrm{A})(\AA)$ & $<\mathrm{DHA}\left({ }^{\circ}\right)$ & $d(\mathrm{D} \cdots \mathrm{A})(\AA)$ & $\mathrm{A}$ \\
\hline $\mathrm{N} 4-\mathrm{H} 41$ & $0.87(2)$ & $2.04(2)$ & $146(1)$ & $2.800(1)$ & $\mathrm{N} 8$ \\
$\mathrm{~N} 4-\mathrm{H} 41$ & $0.87(2)$ & $2.59(1)$ & $113(1)$ & $3.045(1)$ & $\mathrm{N} 1$ \\
$\mathrm{~N} 4-\mathrm{H} 41$ & $0.87(2)$ & $2.57(1)$ & $105(1)$ & $2.928(1)$ & $\mathrm{O} 11$ \\
$\mathrm{~N} 11-\mathrm{H} 111$ & $0.86(2)$ & $2.02(2)$ & $147(1)$ & $2.780(2)$ & $\mathrm{N} 1$ \\
$\mathrm{~N} 11-\mathrm{H} 111$ & $0.86(2)$ & $2.63(2)$ & $112(1)$ & $3.053(1)$ & $\mathrm{N} 8$ \\
$\mathrm{~N} 11-\mathrm{H} 111$ & $0.86(2)$ & $2.68(2)$ & $105(1)$ & $3.008(2)$ & $\mathrm{O} 21$ \\
\hline
\end{tabular}

Table S2. Geometry of the phosphonate moieties in the $\left[\mathrm{Cu}\left(\mathrm{H}_{2} \mathbf{L}^{\mathbf{1}}\right)\right] \cdot 2 \mathrm{H}_{2} \mathrm{O}$ complex

\begin{tabular}{rccc}
\hline \multicolumn{4}{c}{ Distances $(\AA)$} \\
P1-O11 & $1.505(2)$ & $\mathrm{P} 2-\mathrm{O} 21$ & $1.520(2)$ \\
$\mathrm{P} 1-\mathrm{O} 12$ & $1.580(2)$ & $\mathrm{P} 2-\mathrm{O} 22$ & $1.580(2)$ \\
$\mathrm{P} 1-\mathrm{O} 13$ & $1.501(2)$ & $\mathrm{P} 2-\mathrm{O} 23$ & $1.487(2)$ \\
$\mathrm{P} 1-\mathrm{C} 17$ & $1.814(3)$ & $\mathrm{P} 2-\mathrm{C} 18$ & $1.821(3)$ \\
\hline & & Angles $\left({ }^{\circ}\right)$ & \\
\hline O11-P1-O1 & $107.7(1)$ & $\mathrm{O} 21-\mathrm{P} 1-\mathrm{O} 22$ & $110.7(1)$ \\
$\mathrm{O} 11-\mathrm{P} 1-\mathrm{O} 1$ & $117.6(1)$ & $\mathrm{O} 21-\mathrm{P} 1-\mathrm{O} 23$ & $117.5(1)$ \\
$\mathrm{O} 11-\mathrm{P} 1-\mathrm{C} 1$ & $108.9(1)$ & $\mathrm{O} 21-\mathrm{P} 1-\mathrm{C} 18$ & $102.8(1)$ \\
$\mathrm{O} 12-\mathrm{P} 1-\mathrm{O} 1$ & $110.6(1)$ & $\mathrm{O} 22-\mathrm{P} 1-\mathrm{O} 23$ & $107.6(1)$ \\
$\mathrm{O} 12-\mathrm{P} 1-\mathrm{C} 1$ & $105.3(1)$ & $\mathrm{O} 22-\mathrm{P} 1-\mathrm{C} 18$ & $105.0(1)$ \\
O13-P1-C1 & $106.0(1)$ & $\mathrm{O} 23-\mathrm{P} 1-\mathrm{C} 18$ & $112.6(1)$ \\
\hline
\end{tabular}


Table S3. Coordination geometry of the $\left[\mathrm{Cu}\left(\mathrm{H}_{2} \mathbf{L}^{\mathbf{1}}\right)\right]$ found in $\left[\mathrm{Cu}\left(\mathrm{H}_{2} \mathbf{L}^{\mathbf{1}}\right)\right] \cdot 2 \mathrm{H}_{2} \mathrm{O}$ and its comparison with relevant structures deposited in CCDC

\begin{tabular}{|c|c|c|c|c|c|c|c|}
\hline & {$\left[\mathrm{Cu}\left(\mathrm{H}_{2} \mathbf{L}^{1}\right)\right]$} & & $\left.\mathrm{u}\left(\mathrm{H}_{2} \mathbf{L}^{1}\right)\right]$ & {$[\mathrm{Cu}($ Hcb-te2a $)]$} & {$[\mathrm{Cu}(\mathbf{c b}-\mathrm{te} 2 \mathbf{a})]$} & \multirow{2}{*}{\multicolumn{2}{|c|}{$\begin{array}{c}{[\mathrm{Cu}(\mathbf{c b}-\mathbf{t e} 2 \mathrm{a})]} \\
\mathrm{NaClO}_{4} \cdot 1.5 \mathrm{H}_{2} \mathrm{O}\end{array}$}} \\
\hline Parameter & $\cdot 2 \mathrm{H}_{2} \mathrm{O}^{a}$ & \multicolumn{2}{|c|}{$\cdot 0.5 \mathrm{NaCl} \cdot 4 \mathrm{H}_{2} \mathrm{O}^{b}$} & $\left(\mathrm{ClO}_{4}\right)$ & $\cdot \mathrm{NH}_{4} \mathrm{PF}_{6} \cdot \mathrm{H}_{2} \mathrm{O}$ & & \\
\hline CCDC code & & & KUPHEJ & RAZGOP & IXOKIP & \multicolumn{2}{|c|}{ VIQKEL $^{c}$} \\
\hline \multicolumn{8}{|c|}{ Distances $(\AA)$} \\
\hline $\mathrm{Cu}-\mathrm{N} 1$ & $2.045(2)$ & 2.036 & $2.104 / 1.985$ & 2.016 & 2.071 & 2.073 & 2.067 \\
\hline $\mathrm{Cu}-\mathrm{N} 4$ & $2.051(2)$ & 2.041 & $2.033 / 2.096$ & 2.046 & 2.053 & 2.034 & 2.050 \\
\hline $\mathrm{Cu}-\mathrm{N} 8$ & $2.207(2)$ & 2.204 & 2.188 & 2.216 & 2.218 & 2.223 & 2.244 \\
\hline $\mathrm{Cu}-\mathrm{N} 11$ & $2.104(2)$ & 2.087 & 2.094 & 2.057 & 2.048 & 2.027 & 2.042 \\
\hline $\mathrm{Cu}-\mathrm{O} 11$ & $2.716(2)$ & 2.444 & $2.575 / 2.338$ & 2.525 & 2.271 & 2.301 & 2.327 \\
\hline $\mathrm{Cu}-\mathrm{O} 21$ & $1.981(2)$ & 1.998 & 1.992 & 1.966 & 2.018 & 2.008 & 1.998 \\
\hline \multicolumn{8}{|c|}{ Angles $\left(^{\circ}\right)$} \\
\hline $\mathrm{N} 1-\mathrm{Cu}-\mathrm{N} 4$ & $85.55(9)$ & 85.57 & $82.55 / 85.33$ & 87.25 & 88.22 & 88.26 & 88.04 \\
\hline $\mathrm{N} 1-\mathrm{Cu}-\mathrm{N} 8$ & $86.07(9)$ & 86.19 & $80.98 / 94.88$ & 86.37 & 84.83 & 84.82 & 84.53 \\
\hline $\mathrm{N} 1-\mathrm{Cu}-\mathrm{N} 11$ & $97.72(9)$ & 98.12 & $96.27 / 98.98$ & 98.58 & 93.38 & 94.27 & 93.76 \\
\hline $\mathrm{N} 1-\mathrm{Cu}-\mathrm{O} 11$ & $87.81(8)$ & 91.85 & $91.09 / 92.93$ & 93.07 & 90.65 & 88.13 & 88.87 \\
\hline $\mathrm{N} 1-\mathrm{Cu}-\mathrm{O} 21$ & $173.30(9)$ & 174.43 & $172.14 / 170.68$ & 177.02 & 177.49 & 178.38 & 178.43 \\
\hline $\mathrm{N} 4-\mathrm{Cu}-\mathrm{N} 8$ & $98.84(9)$ & 99.69 & $92.62 / 106.08$ & 99.44 & 91.78 & 93.01 & 91.24 \\
\hline $\mathrm{N} 4-\mathrm{Cu}-\mathrm{N} 11$ & 176.03(9) & 174.74 & $176.98 / 168.35$ & 172.93 & 177.69 & 177.46 & 176.45 \\
\hline $\mathrm{N} 4-\mathrm{Cu}-\mathrm{O} 11$ & $79.94(7)$ & 83.81 & $86.14 / 82.28$ & 76.06 & 81.07 & 81.31 & 80.29 \\
\hline $\mathrm{N} 4-\mathrm{Cu}-\mathrm{O} 21$ & 88.43(8) & 88.87 & $93.46 / 87.16$ & 90.05 & 93.79 & 91.84 & 93.49 \\
\hline $\mathrm{N} 8-\mathrm{Cu}-\mathrm{N} 11$ & $83.69(9)$ & 84.35 & 84.44 & 85.00 & 86.72 & 86.96 & 85.89 \\
\hline $\mathrm{N} 8-\mathrm{Cu}-\mathrm{O} 11$ & $173.84(8)$ & 175.83 & $172.06 / 168.98$ & 175.49 & 171.67 & 171.09 & 169.44 \\
\hline $\mathrm{N} 8-\mathrm{Cu}-\mathrm{O} 21$ & $97.76(9)$ & 94.46 & 92.49 & 95.31 & 93.58 & 93.55 & 95.12 \\
\hline $\mathrm{N} 11-\mathrm{Cu}-\mathrm{O} 11$ & $97.87(7)$ & 92.30 & $96.67 / 86.67$ & 99.51 & 100.56 & 99.03 & 102.79 \\
\hline $\mathrm{N} 11-\mathrm{Cu}-\mathrm{O} 21$ & $88.19(9)$ & 87.44 & 87.38 & 84.03 & 84.57 & 85.63 & 84.69 \\
\hline $\mathrm{O} 11-\mathrm{Cu}-\mathrm{O} 22$ & $88.26(7)$ & 87.84 & $95.40 / 80.58$ & 85.07 & 91.16 & 93.49 & 91.69 \\
\hline
\end{tabular}

\footnotetext{
${ }^{a}$ This work. ${ }^{b}$ Two independent complex molecules are present, finding partial disorder of one of them. ${ }^{c}$ Two independent complex molecules were found.
} 
Table S4. Parameters of hydrogen bonds found in the crystal structure of $\left[\mathrm{Cu}\left(\mathrm{H}_{2} \mathbf{L}^{\mathbf{1}}\right)\right] \cdot 2 \mathrm{H}_{2} \mathrm{O}$

\begin{tabular}{lccccl}
\hline \multicolumn{1}{c}{$\mathrm{D}-\mathrm{H}$} & $\begin{array}{c}d(\mathrm{D}-\mathrm{H}) \\
(\AA)\end{array}$ & $\begin{array}{c}d(\mathrm{H} \cdots \mathrm{A}) \\
(\AA)\end{array}$ & $\begin{array}{c}<\mathrm{DHA} \\
\left({ }^{\circ}\right)\end{array}$ & $\begin{array}{c}d(\mathrm{D} \cdots \mathrm{A}) \\
(\AA)\end{array}$ & $\mathrm{A}$ \\
\hline $\mathrm{O} 12-\mathrm{H} 12 \mathrm{O}$ & $0.84(6)$ & $1.76(6)$ & $164(6)$ & $2.573(3)$ & $\mathrm{O} 11[x,-y+2, z+1 / 2]$ \\
$\mathrm{O} 22-\mathrm{H} 22 \mathrm{O}$ & $0.94(6)$ & $1.69(6)$ & $163(5)$ & $2.600(3)$ & $\mathrm{O} 1 \mathrm{~W}$ \\
$\mathrm{O} 1 \mathrm{~W}-\mathrm{H} 11 \mathrm{~W}$ & $0.83(5)$ & $1.95(5)$ & $167(4)$ & $2.762(3)$ & $\mathrm{O} 13$ \\
$\mathrm{O} 1 \mathrm{~W}-\mathrm{H} 12 \mathrm{~W}$ & $0.91(5)$ & $1.92(5)$ & $173(4)$ & $2.819(3)$ & $\mathrm{O} 13[x,-y+2, z-1 / 2]$ \\
$\mathrm{O} 2 \mathrm{~W}-\mathrm{H} 21 \mathrm{~W}$ & $0.89(7)$ & $1.99(7)$ & $155(6)$ & $2.823(3)$ & $\mathrm{O} 23$ \\
$\mathrm{O} 2 \mathrm{~W}-\mathrm{H} 22 \mathrm{~W}$ & $0.78(5)$ & $2.22(5)$ & $151(5)$ & $2.927(3)$ & $\mathrm{O} 23[x,-y+1, z+1 / 2]$ \\
\hline
\end{tabular}

Table S5. Overall protonation constants $\log \beta$ of ligands and overall stability constants $\log \beta$ of $\mathrm{Cu}(\mathrm{II})$ complexes $\left(25^{\circ} \mathrm{C}, I=0.1 \mathrm{M} \mathrm{NMe} 4 \mathrm{Cl}\right)$. Charges are omitted.

\begin{tabular}{cccc}
\hline Species & $\mathrm{H}_{4} \mathbf{L}^{\mathbf{1}}$ & $\mathrm{H}_{4} \mathbf{L}^{\mathbf{2}}$ & $\mathrm{H}_{2} \mathbf{L}^{\mathbf{3}}$ \\
\hline $\mathrm{HL}$ & $15^{a}$ & $15^{a}$ & $15^{a}$ \\
$\mathrm{H}_{2} \mathrm{~L}$ & $26.22(1)$ & $21.89(1)$ & $21.35(1)$ \\
$\mathrm{H}_{3} \mathrm{~L}$ & $33.56(1)$ & $24.49(1)$ & - \\
$\mathrm{H}_{4} \mathrm{~L}$ & $38.19(1)$ & $25.84(1)$ & - \\
\hline$[\mathrm{Cu}(\mathrm{L})]$ & $23.97(13)$ & $20.21(1)$ & $21.28(3)$ \\
{$[\mathrm{Cu}(\mathrm{HL})]$} & $32.23(13)$ & $22.84(1)$ & - \\
{$\left[\mathrm{Cu}\left(\mathrm{H}_{2} \mathrm{~L}\right)\right]$} & $36.86(6)$ & - & - \\
\hline${ }^{a}$ The value cannot be determined and was, thus, fixed at $\log \beta=15$.
\end{tabular}


Figure S5. ${ }^{31}$ P NMR titration of ligands in the alkaline region. Signal shifts of $\mathrm{H}_{4} \mathbf{L}^{\mathbf{1}}(\mathbf{A}), \mathrm{H}_{4} \mathbf{L}^{\mathbf{2}}(\mathbf{B})$ and $\mathrm{H}_{2} \mathbf{L}^{3}(\mathbf{C})$ as a function of $\mathrm{pH}$, adjusting the $\mathrm{pH}$ with $\left(\mathrm{NMe}_{4}\right) \mathrm{OH}$.
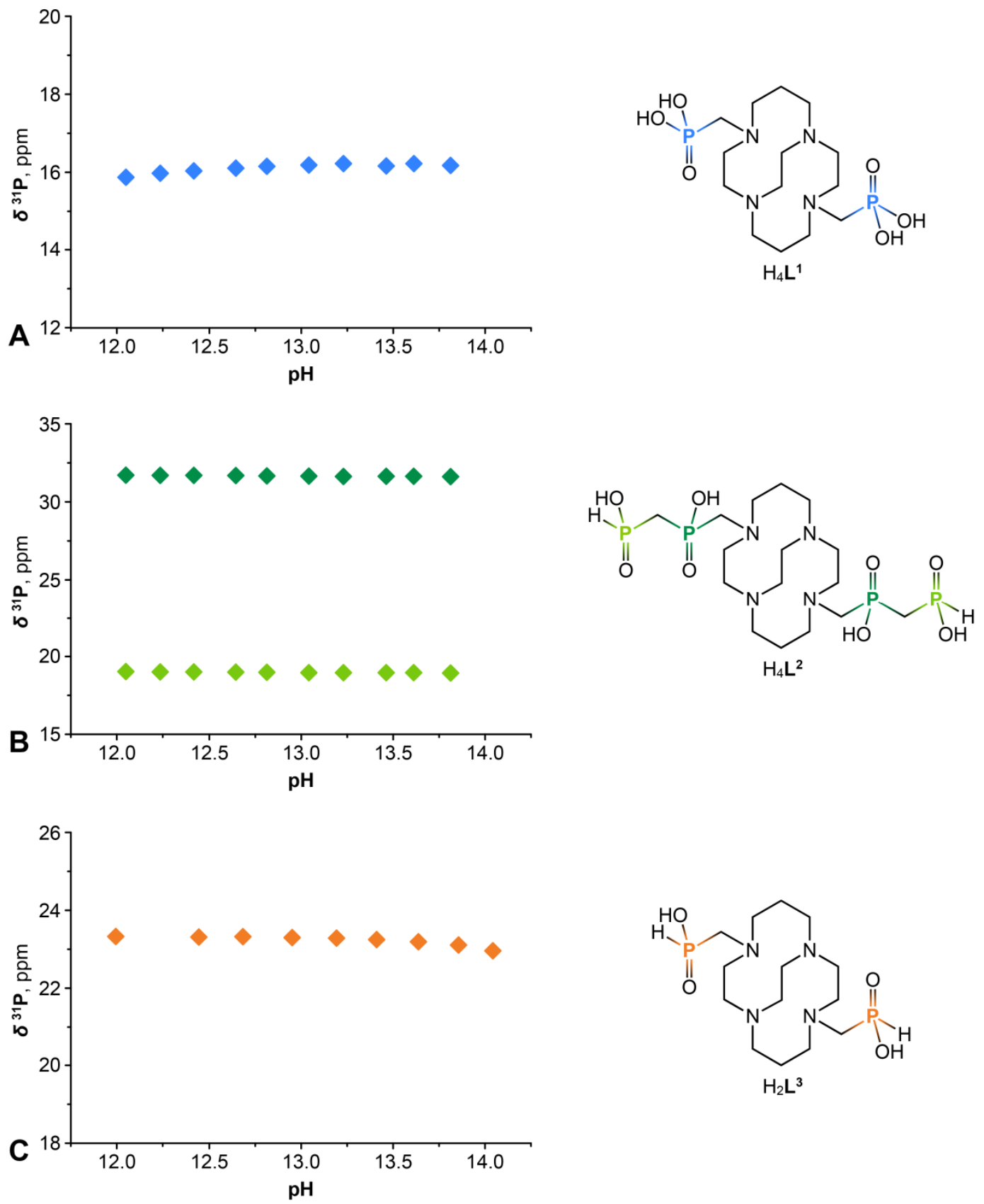
Figure S6. Formation of $\mathrm{Cu}(\mathrm{II})$ complexes: ${ }^{\mathrm{f}} k_{\mathrm{obs}}$ of $\mathrm{H}_{4} \mathbf{L}^{\mathbf{1}}(\mathbf{A}), \mathrm{H}_{4} \mathbf{L}^{2}(\mathbf{B})$ and $\mathrm{H}_{2} \mathbf{L}^{3}(\mathbf{C})$ as function of copper(II) concentration $\left(c_{\mathrm{L}}=0.1 \mathrm{mM}, 25^{\circ} \mathrm{C}\right.$ ) at various $\mathrm{pH}$ values (given in the figures). Only selected curves are displayed. The solid lines represent the best fits according to Equations 2 or 6 .

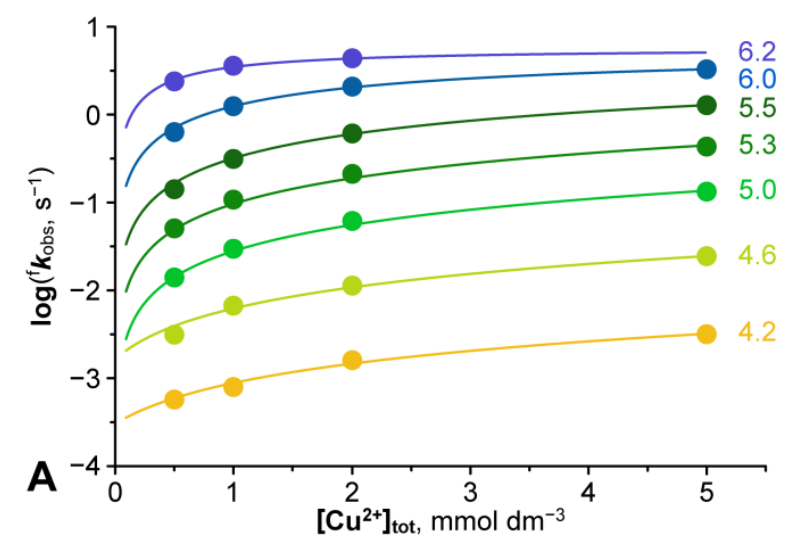<smiles>C#CCN(CCN1CCCN(CP(=O)(O)O)CC1)CCP(=O)(O)O</smiles>
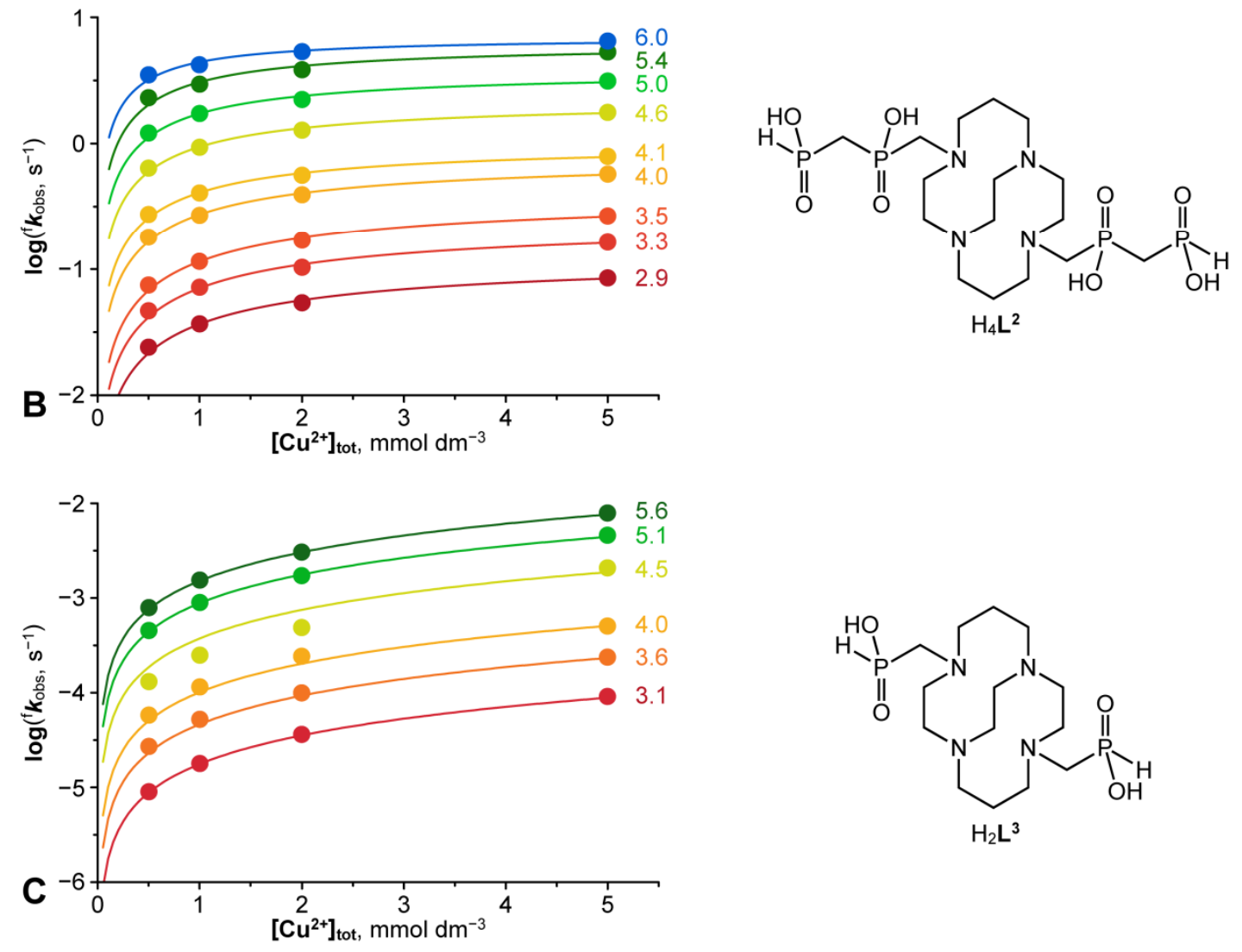


\section{Description of complexation kinetics}

According to the generally accepted complexation mechanism (Scheme 2), complexation of metal ions by macrocyclic ligands with pendant arms containing functional groups with coordinating ability proceeds as a two-step process. The out-of-cage complex (further labeled with an asterisk) is formed in the first equilibrium step. The metal ion in the out-of-cage complex is bound only through pendant oxygen atoms and the macrocycle amin groups are still protonated. The second step is metal binding into the macrocyclic cavity and formation of the in-cage complex. The rate of in-cage complexation is proportional to the concentration of the out-of-cage intermediate, and observed reaction rate $\left({ }^{\mathrm{f}} k_{\mathrm{obs}}\right)$ is expressed by Equation $2^{\dagger}$

$$
{ }^{\mathrm{f}} k_{\text {obs }}=\frac{{ }^{\mathrm{f}} k \cdot K^{*} \cdot[\mathrm{Cu}]_{\text {tot }}}{1+K^{*} \cdot[\mathrm{Cu}]_{\text {tot }}}
$$

where ${ }^{\mathrm{f}} k$ is the rate constant describing the formation of the in-cage complex, $K^{*}$ is the conditional thermodynamic stability constant of the out-of-cage intermediate, and $[\mathrm{Cu}]_{\text {tot }}$ is the overall concentration of $\mathrm{Cu}(\mathrm{II})$ ions.

At any particular $\mathrm{pH}$, the rate of in-cage complexation is proportional to the overall concentration of out-of-cage species and it can be expressed as sum of contributions of differently protonated out-of-cage species (only non-protonated, monoprotonated and diprotonated species are mentioned in the equation)

$$
v={ }^{\mathrm{f}} k \cdot\left([\mathrm{CuL}]^{*}+[\mathrm{CuHL}]^{*}+\left[\mathrm{CuH}_{2} \mathrm{~L}\right]^{*}\right)={ }^{\mathrm{f}} k_{0} \cdot[\mathrm{CuL}]^{*}+{ }^{\mathrm{f}} k_{1} \cdot[\mathrm{CuHL}]^{*}+{ }^{\mathrm{f}} k_{2} \cdot\left[\mathrm{CuH}_{2} \mathrm{~L}\right]^{*}
$$

where ${ }^{\mathrm{f}} k_{n}$ are the rate constants describing the contribution of individual (differently protonated) species. Considering the values of the ligand protonation constants, the out-ofcage complex is present in noticeable concentration in the measured $\mathrm{pH}$ range 3-6 as a mixture of monoprotonated and diprotonated forms (i.e. concentration of $[\mathrm{CuL}]^{*}$ can be neglected when compared to $[\mathrm{CuHL}]^{*}$ and $\left[\mathrm{CuH}_{2} \mathrm{~L}\right]^{*}$, leading to simplification of denominator in the following equation):

$$
{ }^{\mathrm{f}} k \approx \frac{{ }^{f} k_{0}+{ }^{f} k_{1} \cdot K_{\mathrm{p} 1}^{*} \cdot[\mathrm{H}]+{ }^{f} k_{2} \cdot K_{\mathrm{p} 1}^{*} \cdot K_{\mathrm{p} 2}^{*} \cdot[\mathrm{H}]^{2}}{K_{\mathrm{p} 1}^{*} \cdot[\mathrm{H}]+K_{\mathrm{p} 1}^{*} \cdot K_{\mathrm{p} 2}^{*} \cdot[\mathrm{H}]^{2}}
$$

where $K_{\mathrm{p} 1}^{*}$ and $K_{\mathrm{p} 2}^{*}$ are consecutive protonation constants of the mono- and di- protonated out-of-cage species.

Analysis of data has shown that contributions of the non-protonated and diprotonated outof-cage complexes to whole reaction rate (i.e. in numerator of the above equation) are

\footnotetext{
${ }^{\dagger}$ Numbering of equations corresponds to the main text.
} 
negligible in the studied $\mathrm{pH}$ range and, thus, ${ }^{\mathrm{f}} k_{0}$ and ${ }^{\mathrm{f}} k_{2}$ can be omitted. It leads to the simplified formulation of ${ }^{\mathrm{f}} k$ as is expressed by Equation 5

$$
{ }^{\mathrm{f}} k \approx \frac{{ }^{f} k_{1}}{1+K_{\mathrm{p} 2}^{*} \cdot[\mathrm{H}]}
$$

\section{Description of dissociation kinetics}

Dissociation rate at particular $\mathrm{pH}$ is proportional to the overall concentration of the complex and it could be also expressed as sum of contributions of kinetically active protonated species

$$
v={ }^{\mathrm{d}} k_{\mathrm{obs}} \cdot[\mathrm{CuL}]_{\mathrm{tot}}={ }^{\mathrm{d}} k_{n+1} \cdot[\mathrm{CuHL}]+{ }^{\mathrm{d}} k_{n+2} \cdot\left[\mathrm{CuH}_{2} \mathrm{~L}\right]
$$

where ${ }^{\mathrm{d}} k_{n+1}$ and ${ }^{\mathrm{d}} k_{n+2}$ are the rate constants that correspond to the dissociation of species bearing more protons (by one and two) than is present in thermodynamically stable species. Then, the observed rate constant is expressed by Equation $8^{\ddagger}$

$$
\mathrm{d}_{k_{\mathrm{obs}}}=\frac{{ }^{d} k_{n+1} \cdot K_{\mathrm{H} n+1} \cdot[\mathrm{H}]+{ }^{d} k_{n+2} \cdot K_{\mathrm{H} n+1} \cdot K_{\mathrm{H} n+2} \cdot[\mathrm{H}]^{2}}{1+K_{\mathrm{H} n+1} \cdot[\mathrm{H}]+K_{\mathrm{H} n+1} \cdot K_{\mathrm{H} n+2} \cdot[\mathrm{H}]^{2}}
$$

where $K_{\mathrm{Hn}+1}$ and $K_{\mathrm{Hn}+2}$ are consecutive protonation constants of the complex. If protonation takes place only in very acidic solutions, i.e. logarithms of protonation constants of the complex are $\log K_{n} \ll<$, then complex is present only in the nonprotonated state and $K_{\mathrm{H} n+1}$. $[\mathrm{H}]+K_{\mathrm{H} n+1} \cdot K_{\mathrm{H} n+2} \cdot[\mathrm{H}]^{2} \ll 1$. Thus, Equation 8 can be simplified, expressing ${ }^{\mathrm{d}} k_{\mathrm{obs}}$ according to Equation 9

$$
\begin{aligned}
& { }^{\mathrm{d}} k_{\mathrm{obs}}={ }^{d} k_{\mathrm{H} n+1} \cdot[\mathrm{H}]+{ }^{d} k_{\mathrm{H} n+2} \cdot[\mathrm{H}]^{2} \\
& \text { where }{ }^{\mathrm{d}} k_{\mathrm{H} n+1}={ }^{\mathrm{d}} k_{n+1} \cdot K_{\mathrm{H} n+1} \text { and }{ }^{\mathrm{d}} k_{\mathrm{H} n+2}={ }^{\mathrm{d}} k_{n+2} \cdot K_{\mathrm{H} n+1} \cdot K_{\mathrm{H} n+2} .
\end{aligned}
$$

* Numbering of equations corresponds to the main text. 
Scheme S1. Formal reaction scheme for the formation of the in-cage $\mathrm{Cu}(\mathrm{II})$ complexes. Charges of ligand and complex species are omitted.

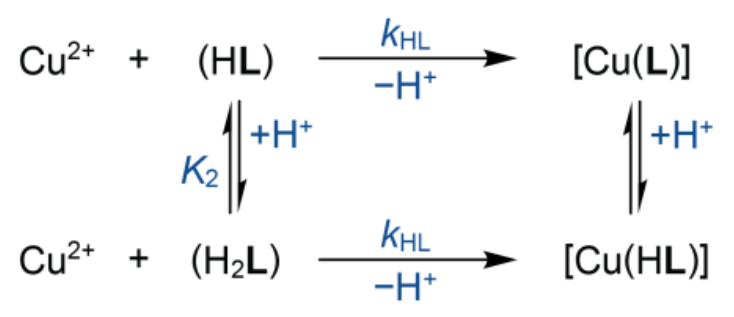

Figure S7. Comparison of the determined formation rate constants ${ }^{\mathrm{f}} k_{\mathrm{obs}}\left(c_{\mathrm{L}}=0.1 \mathrm{mM}, c_{\mathrm{Cu}}=1 \mathrm{mM}\right.$, $25^{\circ} \mathrm{C}$ ) of $\mathrm{H}_{4} \mathbf{L}^{\mathbf{1}}$ (blue), $\mathrm{H}_{4} \mathbf{L}^{2}$ (light green), $\mathrm{H}_{2} \mathbf{L}^{3}$ (orange), $\mathrm{H}_{2}$ te1bpin (dark green, adopted from ref. 1; it corresponds to the formation of the initially formed in-cage complex) and $\mathrm{H}_{4} \mathbf{t e}^{\mathbf{2}} \mathbf{p}^{\mathbf{1 , 8}}$ (red line, calculated from data in ref. 2).
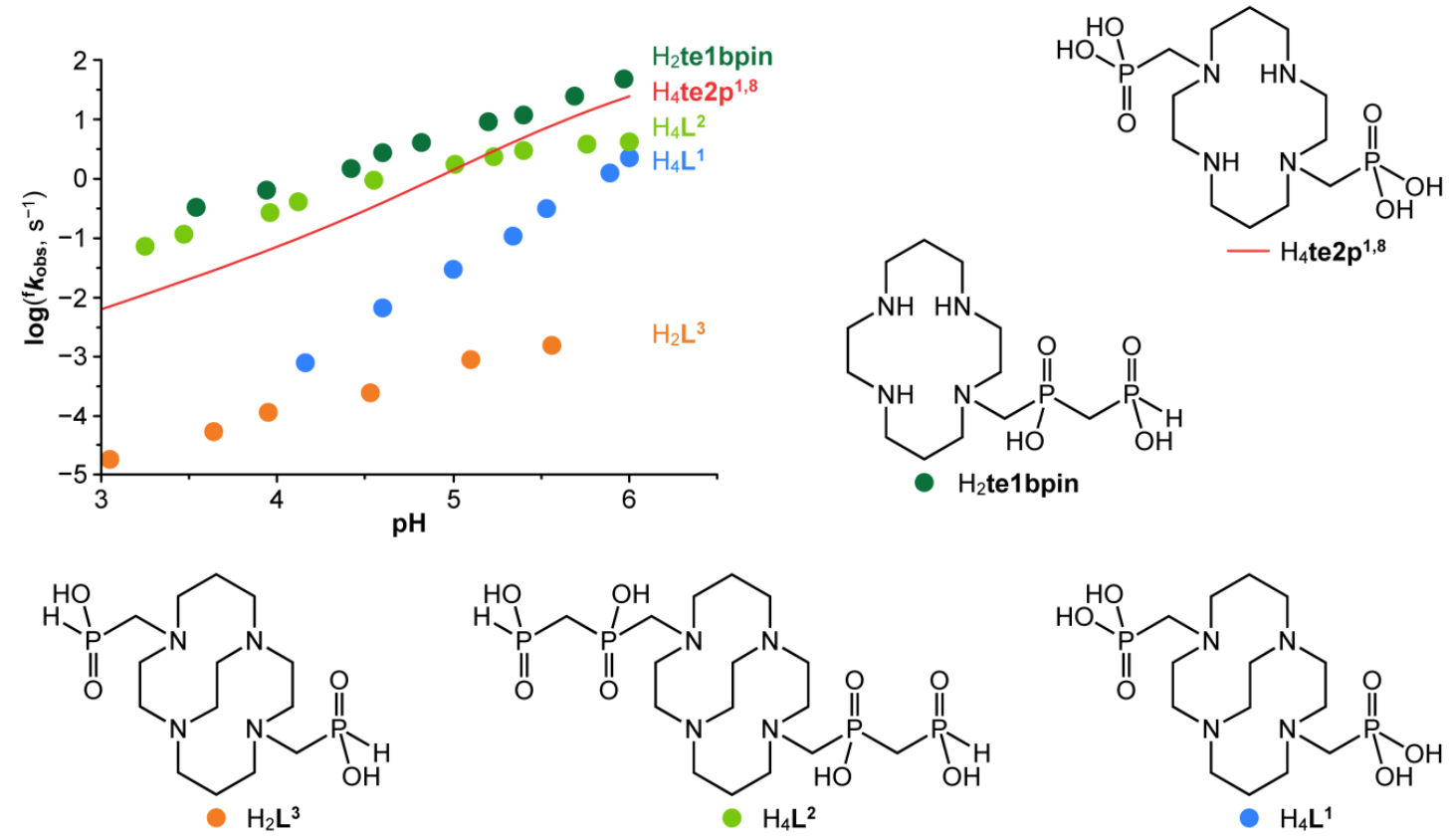
Figure S8. Dissociation rate constants ${ }^{\mathrm{d}} k_{\mathrm{obs}}$ of $\mathrm{Cu}(\mathrm{II})-\mathrm{H}_{4} \mathbf{L}^{\mathbf{1}}$ (A, blue), $\mathrm{Cu}(\mathrm{II})-\mathrm{H}_{4} \mathbf{L}^{2}$ (B, green) and $\mathrm{Cu}$ (II)- $\mathrm{H}_{2} \mathbf{L}^{\mathbf{1}}$ (C), orange) $\left(c_{\mathrm{CuL}}=1 \mathrm{mM}, 90{ }^{\circ} \mathrm{C}, I=5 \mathrm{M} \mathrm{H} / \mathrm{NaClO}_{4}\right)$. The lines represent the best fits according to Equations 8 or 9 .
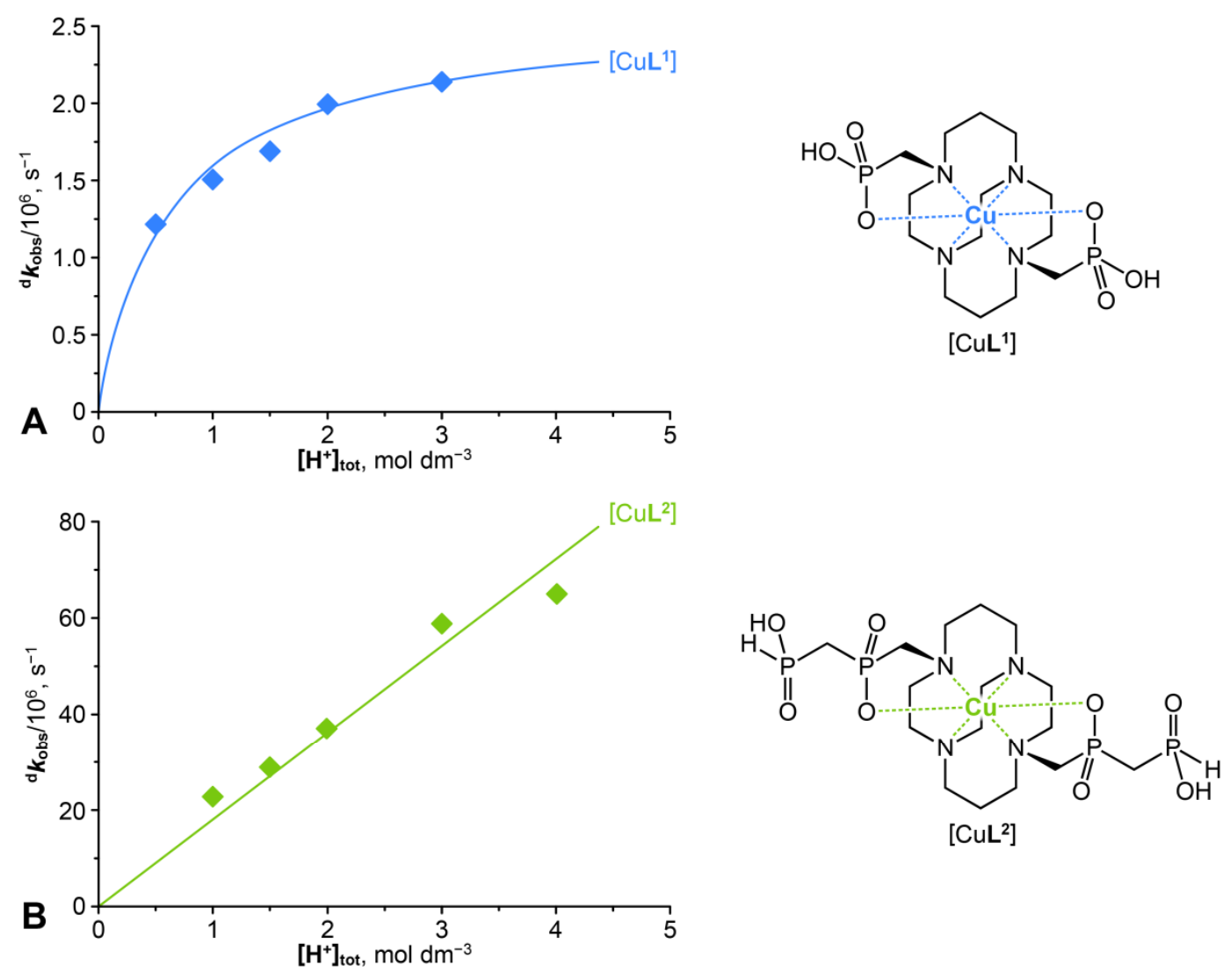

[CuL']
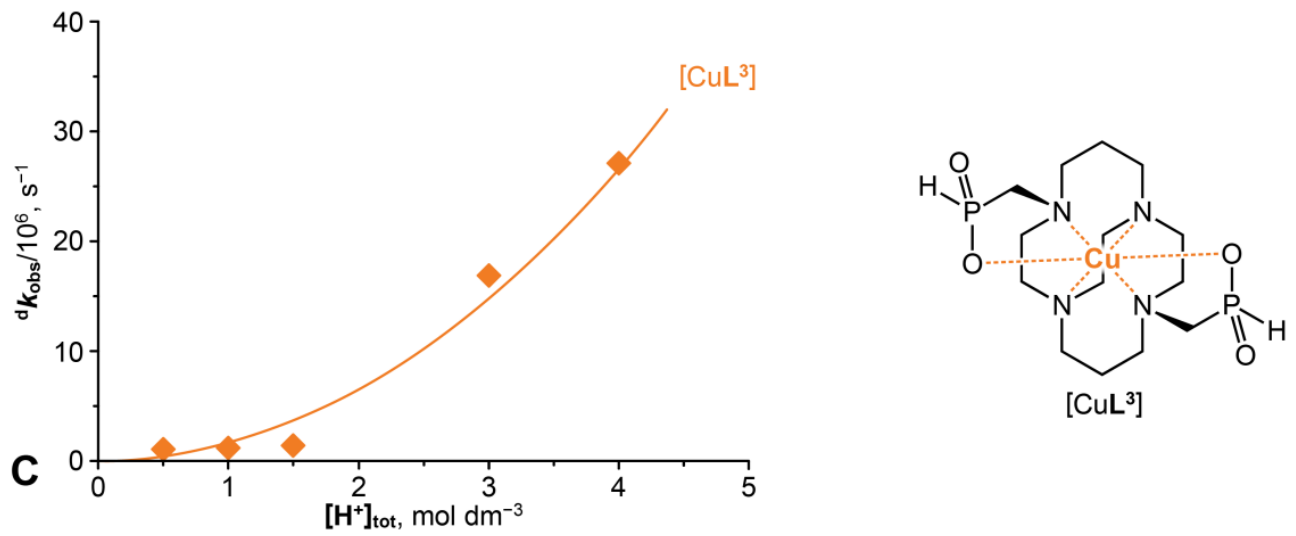
Figure S9. Comparison of dissociation rate constants ${ }^{\mathrm{d}} k_{\text {obs }}$ of $\mathrm{Cu}(\mathrm{II})-\mathrm{H}_{4} \mathbf{L}^{2}$ in $\mathrm{HClO}_{4}$ (light green) and in $\mathrm{HCl}$ (dark green) $\left(c_{\mathrm{CuL}}=1 \mathrm{mM}, 90{ }^{\circ} \mathrm{C}, I=5 \mathrm{M} \mathrm{H} / \mathrm{NaClO}_{4}\right.$ or $\left.\mathrm{H} / \mathrm{NaCl}\right)$.
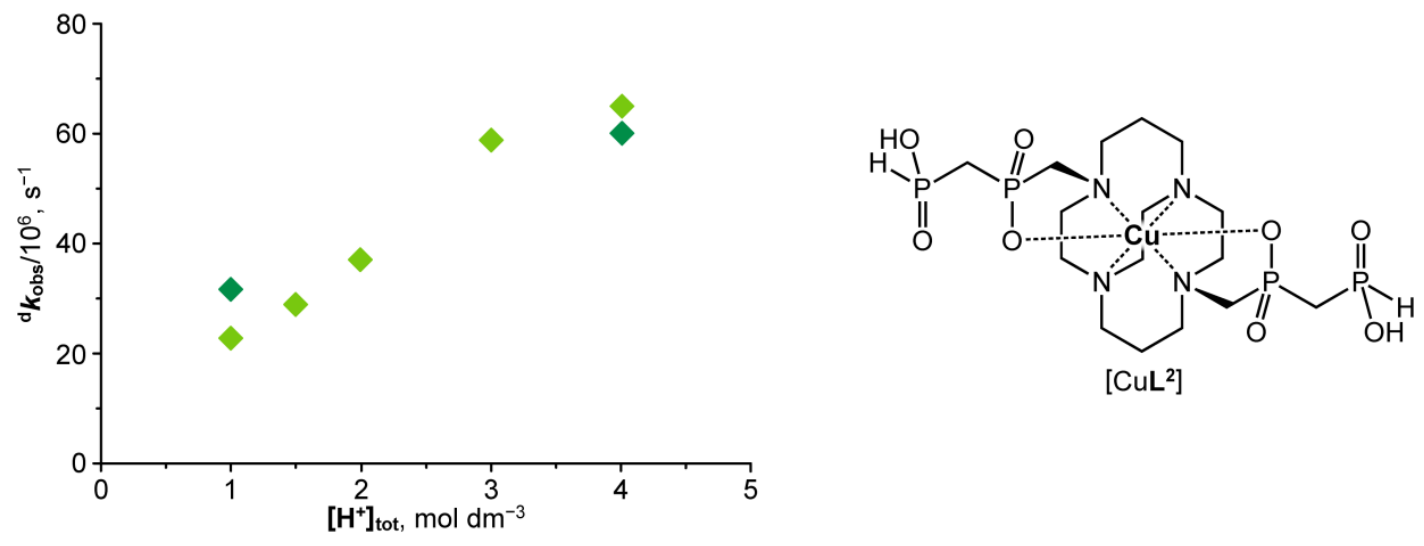
Table S6. X-ray crystal data collection and refinement details

\begin{tabular}{|c|c|c|c|}
\hline Parameter & $\mathrm{H}_{2} \mathbf{L}^{3} \cdot 5 \mathrm{H}_{2} \mathrm{O}$ & {$\left[\mathrm{Cu}\left(\mathrm{H}_{2} \mathbf{L}^{\mathbf{1}}\right)\right] \cdot 2 \mathrm{H}_{2} \mathrm{O}$} & $N, N^{\prime \prime}$-Dibenzyl-cb-cyclam \\
\hline Formula & $\mathrm{C}_{14} \mathrm{H}_{42} \mathrm{~N}_{4} \mathrm{O}_{9} \mathrm{P}_{2}$ & $\mathrm{C}_{14} \mathrm{H}_{34} \mathrm{CuN}_{4} \mathrm{O}_{8} \mathrm{P}_{2}$ & $\mathrm{C}_{26} \mathrm{H}_{38} \mathrm{~N}_{4}$ \\
\hline$M_{\mathrm{r}}$ & 472.45 & 511.93 & 406.60 \\
\hline Habit & plate & prism & prism \\
\hline Color & colorless & blue & colorless \\
\hline Crystal system & triclinic & monoclinic & triclinic \\
\hline Space group & $P-1$ & $C c$ & $P-1$ \\
\hline$a(\AA)$ & $8.25370(10)$ & $15.0444(3)$ & $11.8352(3)$ \\
\hline$b(\AA)$ & $12.0387(3)$ & $14.8121(3)$ & $12.1285(2)$ \\
\hline$c(\AA)$ & $12.3127(3)$ & $9.1358(2)$ & $17.4415(4)$ \\
\hline$\alpha\left(^{\circ}\right)$ & $104.7529(10)$ & 90 & $77.6745(12)$ \\
\hline$\beta\left(^{\circ}\right)$ & $90.9996(13)$ & $100.3615(12)$ & 89.8743(9) \\
\hline$\gamma\left({ }^{\circ}\right)$ & $107.1201(13)$ & 90 & $75.0877(11)$ \\
\hline$U, \AA^{3}$ & $1125.01(4)$ & 2002.61(7) & 2359.84(9) \\
\hline$Z$ & 2 & 4 & 4 \\
\hline$D_{\text {calc }}, \mathrm{g} \mathrm{cm}^{-3}$ & 1.395 & 1.698 & 1.144 \\
\hline$\mu, \mathrm{mm}^{-1}$ & 0.245 & 1.302 & 0.068 \\
\hline Unique refl. & 5107 & 4426 & 10840 \\
\hline $\begin{array}{l}\text { Obsd. refl. } \\
(I>2 \sigma(I))\end{array}$ & 4545 & 4368 & 7954 \\
\hline$R(I>2 \sigma(I))$ & 0.0319 & 0.0209 & 0.0431 \\
\hline$R^{\prime}($ all $)$ & 0.0369 & 0.0213 & 0.0671 \\
\hline$w R(I>2 \sigma(I))$ & 0.0840 & 0.0513 & 0.0962 \\
\hline$w R^{\prime}($ all $)$ & 0.0876 & 0.0516 & 0.1081 \\
\hline
\end{tabular}


Figure S10: Single crystals of a key starting compound - $N, N^{\prime \prime}$-dibenzyl-cb-cyclam - enabled the determination of its crystal structure. The structural parameters differ from a recently published structure of this compound. ${ }^{3}$ In the present case, two independent molecules were found (one of them is shown in $\mathbf{A}$; hydrogen atoms are not displayed). However, both units have very similar geometry (overlay of both independent molecules is shown in B). Furthermore, both independent units are very similar to that in the recently published structure - only slightly differing in the position of the benzyl groups. Overlay of the present structure (red and blue) with the recently reported crystal structure (green, miwpeq, CCDC-1555222) 3 is shown in $\mathbf{C}$.

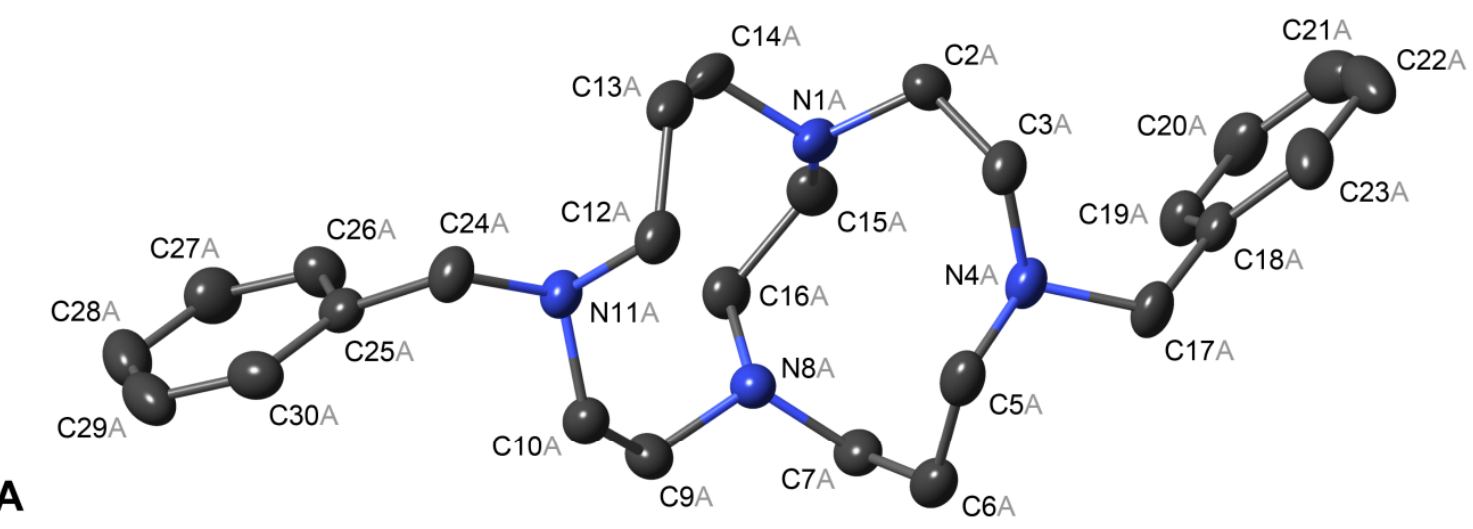

B

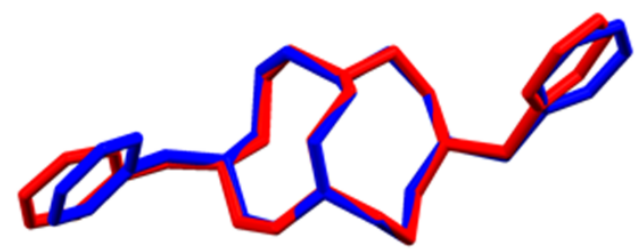

C

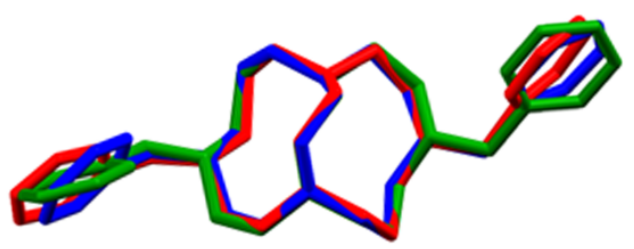




\section{References}

${ }^{1}$ David, T.; Kubíček, V.; Gutten, O.; Lubal, P.; Kotek, J.; Pietzsch, H.-J.; Rulíšek, L.; Hermann, P. Cyclam Derivatives with a Bis(phosphinate) or a Phosphinato-Phosphonate Pendant Arm: Ligands for Fast and Efficient Copper(II) Complexation for Nuclear Medical Applications. Inorg. Chem. 2015, 54, 11751-11766.

${ }^{2}$ Kotek, J.; Lubal, P.; Hermann, P.; Císařová, I.; Lukeš, I.; Godula, T.; Svobodová, I.; Táborský, P.; Havel, J. Unusually High Thermodynamic Stability and Extraordinary Kinetic Inertness of Copper(II) Complexes with 1,4,8,11-Tetraazacyclotetradecane-1,8bis(methylphosphonic Acid). Example of a Rare Isomerism Between Kinetically Inert Pentaand Hexacoordinated Copper(II) Complexes. Chem. Eur. J. 2003, 9, 233-248.

${ }^{3}$ Hubin, T. J.; Walker, A. N.; Davilla; D. J.; Freeman, T. N. C.; Epley, B. M.; Hasley, T. R.; Amoyaw, P. N. A.; Jain, S.; Archibald, S. J.; Prior, T. J.; Krause, J. A.; Oliver, A. G.;

Tekwani, B. L.; Khan, M. O. F. Tetraazamacrocyclic derivatives and their metal complexes as antileishmanial leads. Polyhedron 2019, 163, 42-53. 